\title{
The Use of Silica Supported Nickel-Copper Oxide Catalyst for Photodegradation of Methylene Blue
}

\section{ANTI KOLONIAL PRODJOSANTOSO*, FARRASIYA INDIKA SHELMA, KUN SRI BUDIASIH and MAXIMUS PRANJOTO UTOMO}

\begin{abstract}
Department of Chemistry, Yogyakarta State University, Yogyakarta, 55281, Indonesia.
*Corresponding author E-mail: prodjosantoso@uny.ac.id
\end{abstract}

http://dx.doi.org/10.13005/ojc/350423

(Received: July 02, 2019; Accepted: August 06, 2019)

\begin{abstract}
Photodegradation is a safe and low cost methods to clean water bodies from some organic pollutants. The method has been developed in term of increasing the efficiency of the degradation capacity of photocatalyst. The photocatalyst working under visible light is the most desirable. The preparation of silica supported nickel-copper oxide $\left[(\mathrm{Ni}-\mathrm{Cu}) \mathrm{O}_{x} @ \mathrm{SiO}_{2}\right]$ catalyst and the use of the catalyst in the photodegradation of methylene blue in the water were studied. The catalyst was prepared by impregnating the silica support into the mixture of nickel and copper salts, followed by calcination at $800^{\circ} \mathrm{C}$ for 4 hours. A series method of XRD, SEM- EDX, and UV-Vis, Diffuse Reflectance has been used to characterize the catalyst. The catalyst adsorption test was undertaken in the dark, and the catalyst activity test for photodegradation of methylene blue was conducted under the sunlight. The XRD diffractogram of as prepared $(\mathrm{Ni}-\mathrm{Cu}) \mathrm{O}_{\mathbf{x}} @ \mathrm{SiO}_{2}$ shows a weak-wide peak at $2 \theta=21.8^{\circ}$ indicating $\mathrm{SiO}_{2}$ tridymite, and has a crystallite size of $10.38 \mathrm{~nm}$. The combination method of SEM and EDX confirms the formation of $(\mathrm{Ni}-\mathrm{Cu}) \mathrm{O}_{\mathrm{x}} @ \mathrm{SiO}_{2}$. The $(\mathrm{Ni}-\mathrm{Cu}) \mathrm{O}_{\mathrm{x}} @ \mathrm{SiO}_{2}$ catalyst has a relatively low bandgap energy and shows a good activity for photodegradation of blue methylene under sunlight. The adsorption of the methylene blue on the $(\mathrm{Ni}-\mathrm{Cu}) \mathrm{O}_{x} @ \mathrm{SiO}_{2}$ follows the Langmuir isotherm pattern.
\end{abstract}

Keywords: $\mathrm{SiO}_{2},(\mathrm{Ni}-\mathrm{Cu}) \mathrm{O}_{\mathrm{x}} @ \mathrm{SiO}_{2}$, Impregnation, Photocatalyst, Methylene blue.

\section{INTRODUCTION}

Textile industry is one of the fastest growing industries in Indonesia. ${ }^{1}$ The rapid development of the textile industry poses a problem for the environment, especially the problem caused by textile dyeing liquid waste. The liquid waste contains toxic and dangerous compounds. The liquid waste in the waters can kill water organisms and block sunlight from penetrating the aquatic environment, thus disrupting the biological processes. ${ }^{2}$

Discharged dyestuffs from textile industry are generally in the form of organic compounds that are bio-nondegradable and difficult to be decomposed. ${ }^{3}$ Dyes often used in the textile industry are methylene blue, methyl orange, and Congo red. Methylene blue is a cationic heterocyclic aromatic

This is an Open Access article licensed under a Creative Commons license: Attribution 4.0 International (CC- BY). Published by Oriental Scientific Publishing Company @ 2018 
compound commonly used as basic leather, cloth, and fabric coloring. The threshold limit value of methylene blue is $5-10 \mathrm{mg} / \mathrm{L}$.

The conventional method for reducing the levels of methylene blue in water includes chlorination, ozonation, and adsorption using activated carbon., ${ }^{4,5}$ New methods which are easy to implement and relatively inexpensive need to be developed. One of these is photodegradation using a combination of semi-conductor photocatalyst and ultraviolet light. 6,7 Harraz et al., (2019) was successful in engineering the photodegradation of methylene blue under UV and visible light using $\mathrm{TiO}_{2} @ \mathrm{SiO}_{2}$. photocatalyst. $^{8}$ The photodegradation will be more costly effective if undertaken under the sunlight. ${ }^{9}$

The use of photocatalyst has advantages because it can mineralize the total organic pollutants including the textile waste (azo compounds), the cost of their use is cheap and the process is relatively fast, non-toxic and has long-term use capability. ${ }^{9,10}$ The ability of the photocatalyst can be improved by applying materials such as $\mathrm{TiO}_{2}, \mathrm{ZnO}, \mathrm{Fe}_{2} \mathrm{O}_{3}$, $\mathrm{CdS}$, and $\mathrm{ZnS}$ which have semiconductor properties. ${ }^{11-13}$ However, the materials have a relatively expensive price. Therefore, semiconductor materials need to be supported by inexpensive compounds such as silica $\left(\mathrm{SiO}_{2}\right) \cdot{ }^{14,15}$

Nickel and copper oxides are semiconductor materials. The bandgap energy of $\mathrm{NiO}$ and $\mathrm{CuO}$ is $>3 \mathrm{eV}$ and $2-3 \mathrm{eV}$, respectively. ${ }^{16,17}$ To lower the bandgap of $\mathrm{SiO}_{2}$ which is about $9 \mathrm{eV}$ the nickel and copper oxides may be supported on the surface of silica. Silica-supported nickel and copper oxides are expected to work as a photocatalyst of methylene blue under sunlight.

\section{MATERIALS AND METHODS}

Materials including $\mathrm{SiO}_{2}$ (Merck \& Co., 99.3\%), $\mathrm{Ni}\left(\mathrm{NO}_{3}\right)_{2} \cdot 3 \mathrm{H}_{2} \mathrm{O}$ (Merck \& Co., 99. 99\%), $\mathrm{Cu}\left(\mathrm{NO}_{3}\right)_{2} 3 \mathrm{H}_{2} \mathrm{O}$ (Merck \& Co, 99-104\%), and Metilen Blue, are used without any prior treatment.

The (Ni-Cu)Ox@SiO ${ }_{2}$ catalyst was prepared by mixing a proportional amount of $\mathrm{Ni}\left(\mathrm{NO}_{3}\right)_{2} \cdot 3 \mathrm{H}_{2} \mathrm{O}$, $\mathrm{Cu}\left(\mathrm{NO}_{3}\right)_{2} \cdot 3 \mathrm{H}_{2} \mathrm{O}$ and $\mathrm{SiO}_{2}$, and distilled water to a volume of $30 \mathrm{~mL}$. The mixture was stirred using a magnetic stirrer and evaporated. Nearly dry mixture was added with ethanol, then methanol, stirred and filtered. The residue was air dried for $24 \mathrm{~h}$ and calcined at $800^{\circ} \mathrm{C}$ for 4 hours.
The XRD diffractogram of (Ni-Cu)Ox@ $\mathrm{SiO}_{2}$ catalyst was obtained by using X-Ray. Diffraction Rigaku Multiflex, and $\mathrm{Cu}-\mathrm{K} \alpha$ radiation in the range $2 \theta$ from $5^{\circ}-80^{\circ}$. The UV-Vis spectrum of the samples were recorded as a function of wavelength using the UV-Vis 1700 Pharmaspec Spectrophotometer Specular Reflectance. The samples were put into cuvettes and the absorbances were measured in a wavelength range of 200-800 $\mathrm{nm}$. The samples of $(\mathrm{Ni}-\mathrm{Cu}) \mathrm{Ox} @ \mathrm{SiO}_{2}$ were qualitatively analyzed using Scanning Electron Microscopy-Electron Dispersive X-Ray Analyzer JEOL JED-2300 working at $15 \mathrm{kV}$. Dark adsorption test was undertaken by mixing $0.1 \mathrm{~g}$ of the (Ni-Cu)Ox@ $\mathrm{SiO}_{2}$ catalyst with $50 \mathrm{ml}$ of $10 \mathrm{ppm}$ methylene blue solution in a $100 \mathrm{~mL}$ Erlenmeyer. The mixture was stirred in a dark room. The absorption of the filtrate was measured at the time interval of $0,5,10,15,20,25,35,65,95$, and $125 \mathrm{~min}$ and at a wavelength of $663 \mathrm{~nm}$.

Photocatalyst activity of the (Ni-Cu)Ox@ $\mathrm{SiO}_{2}$ under sunlight was measured by mixing $0.1 \mathrm{~g}$ of the catalyst with $50 \mathrm{ml}$ of $10 \mathrm{ppm}$ methylene blue solution in a $100 \mathrm{ml}$ Erlenmeyer. The mixture was exposed under the sunlight, and the absorbance of the filtrate was observed after 0, 5, 10, 15, 20, 25, $35,65,95$, and $125 \mathrm{~min}$ of the sunlight exposure, at a wavelength of $663 \mathrm{~nm}$.

\section{RESULTS AND DISSCUSSION}

The grayish white of (Ni-Cu)Ox@ $\mathrm{SiO}_{2}$ catalysts were successfully synthesized. The XRD spectra indicate the presence of a broad-weak peak at $2 \theta=21.8^{\circ}$ (Fig. 1.), which is a diffraction of $\mathrm{SiO}_{2}$ tridymite (JCPDS No. 39-1425). Crystal size of $(\mathrm{Ni}-\mathrm{Cu}) \mathrm{Ox} @ \mathrm{SiO}_{2}$ calculated using the Scherrer equation is $10.38 \mathrm{~nm} .{ }^{18,19}$

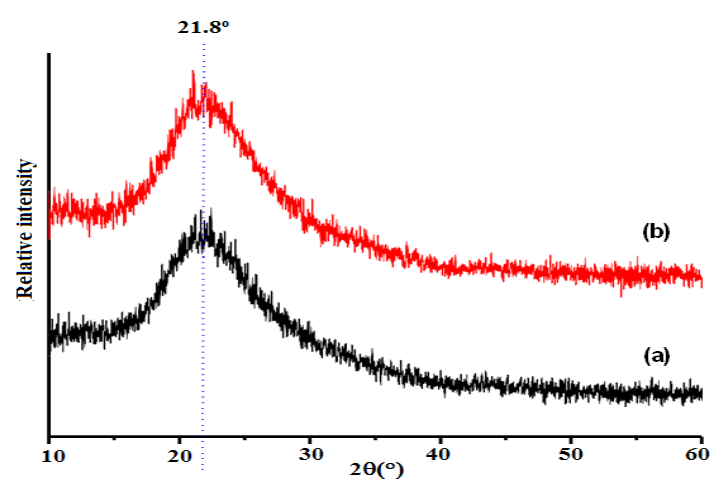

Fig. 1. The XRD difractogram of $(\mathrm{Ni}-\mathrm{Cu}) \mathrm{Ox} @ \mathrm{SiO}_{2}$, $\mathrm{Ni}: \mathrm{Cu}=(\mathrm{a})$ 0.2:0.1 and (b) 0.15:0.15 
Unfortunately, the combination of SEMEDX method is failed to prove the presence of both nickel and copper species on the surface of $\mathrm{SiO}_{2}$.

The micrographs only indicate the silica species, that is $\mathrm{SiO}_{2}$ having particle size of between 0.1 - $15 \mu \mathrm{m}$ (Fig. 2). The EDX analysis suggests that both nickel and copper species are under limitation of EDX measurement (Figure 3).

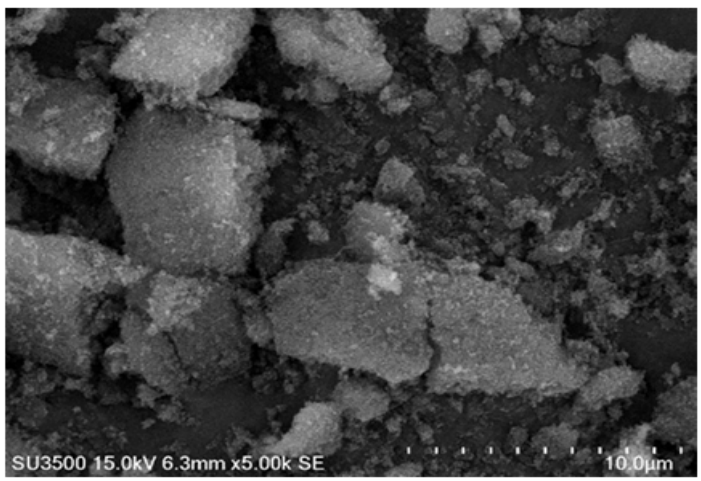

(a)

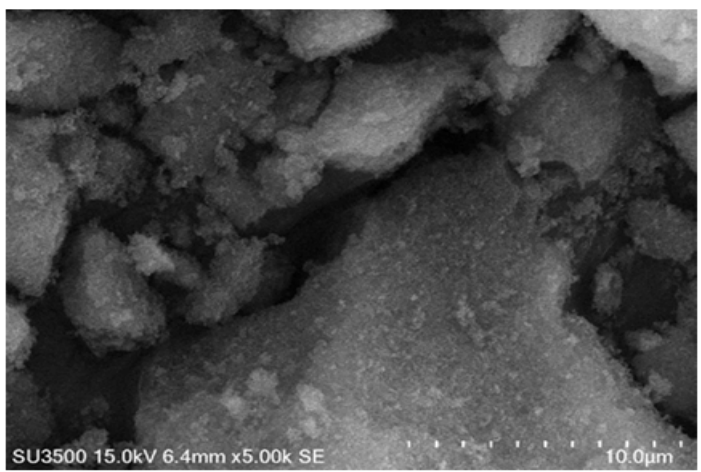

(b)

Fig. 2. The SEM micrograph of (Ni-Cu)Ox@ $@ \mathrm{SiO}_{2}$, $\mathrm{Ni}: \mathrm{Cu}=$ (a) 0.2:0.1 and (b) 0.15:0.15

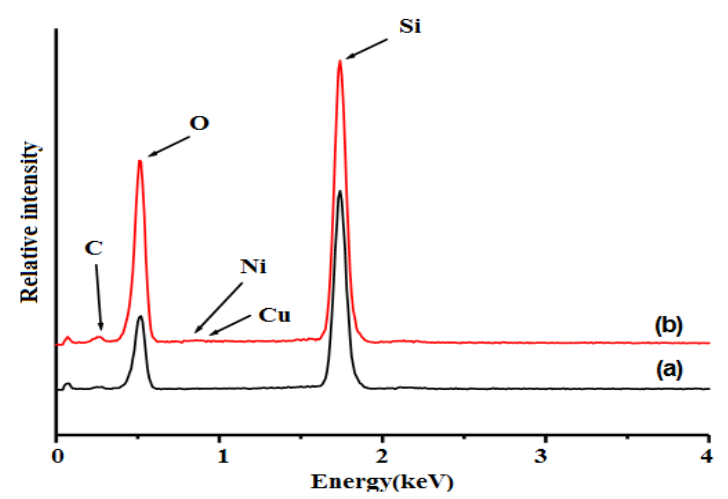

Fig. 3. The EDX spectra of (Ni-Cu)Ox@ $\mathrm{SiO}_{2}$, $\mathrm{Ni}: \mathrm{Cu}=$ (a) 0.2:0.1 and (b) 0.15:0.15
UV-Vis Diffuse Reflectance method was applied to measure energy absorbance of samples at wavelength between $200-800 \mathrm{~nm}$. It has been postulated that the UV spectrum ranges from 200-400 $\mathrm{nm}$, while the visible spectrum ranges from 400-800 nm. All samples indicate peaks at UV and visible wavelenght (Table 1). These prove that the nickel and copper specieses are supported on the surface of $\mathrm{SiO}_{2}$, since $\mathrm{SiO}_{2}$ absorbs the energy at low wavelength.

\begin{tabular}{ccc}
\multicolumn{3}{c}{ Table 1: Absorbances of (Ni-Cu)Ox @ } \\
$\mathrm{SiO}_{2}$ catalysts \\
\begin{tabular}{ccc}
\multicolumn{2}{c}{$\lambda(\mathrm{nm})$} \\
(Ni-Cu)Ox@ $\mathrm{SiO}_{2}, \mathrm{Ni}: \mathrm{Cu}=$ & \multicolumn{3}{c}{ Visibel } & UV \\
\hline $0.3: 0.0$ & 331 & 264 \\
$0.2: 0.1$ & 331 & 252 \\
$0.15: 0.15$ & 320 & - \\
\hline
\end{tabular}
\end{tabular}

Bandgap energy affects the photocatalytic ability of $(\mathrm{Ni}-\mathrm{Cu}) \mathrm{Ox} @ \mathrm{SiO}_{2}$ catalyst. The reflectance data (REF) of the diffuse reflectance UV-Vis measurement is used in the calculation using the Kubelka-Munk equation to obtain the bandgap energy $(\mathrm{Eg})$ of $(\mathrm{Ni}-\mathrm{Cu}) \mathrm{Ox} @ \mathrm{SiO}_{2} \cdot{ }^{20}$ The calculation of bandgap energy by the Kubelka-Munk method include a graph of the relationship between $\mathrm{eV}$ and $\left(F\left(R^{\prime} \propto x h v\right)\right)^{1 / 2}$ presented in (Figure 4).

(Figure 4) describes that bandgap energies of (Ni-Cu)Ox@ $\mathrm{SiO}_{2}, \mathrm{Ni}: \mathrm{Cu}=0.3: 0.0,0.2: 0.1$ and 0.15:0.15 are between 3.40-2.58 eV, 4.62-2.31 eV, and 3.34-2.41 eV, respectively. Steiner, et al., (1992) found that $\mathrm{NiO}$ bandgap energy is $\sim 4 \mathrm{eV},{ }^{21}$ while the $\mathrm{CuO}$ has an energy bandgap between 1.85-2.4 eV and are effectively operated under UV and visible lights. ${ }^{22}$ This promises that the $(\mathrm{Ni}-\mathrm{Cu}) \mathrm{Ox} @ \mathrm{SiO}_{2}$ catalyst is also effectively used under sunlight.

The absorption study of (Ni-Cu)Ox@ $\mathrm{SiO}_{2}$ on methylene blue is carried out in the dark room. This experiment facilitates the determination of the ability of the catalyst to absorb methylene blue without obstruction of light. The concentration of methylene blue before and after adsorption measured at any times is listed in (Table 2).

The (Ni-Cu)Ox@SiO, catalyst absorption capacity was calculated by using the Langmuir and 
Freundlich equations. ${ }^{23} \mathrm{~A}$ plot of the concentration of methylene blue adsorbed in each $1 \mathrm{~g}$ of catalyst $(\mathrm{C} / \mathrm{m})$ versus the final methylene blue concentration (C) is used to determine the Langmuir isotherm pattern, and a plot of the log amount of methylene blue adsorbed on every $1 \mathrm{~g}$ of catalyst $\left(\log X_{\mathrm{m}} / \mathrm{m}\right)$ versus a log concentration of methylene blue after adsorption $\left(\log C_{t}\right)$ is used to determine the pattern of Freundlich isotherm. Line equations are obtained from the plots of Langmuir and Freundlich isotherms

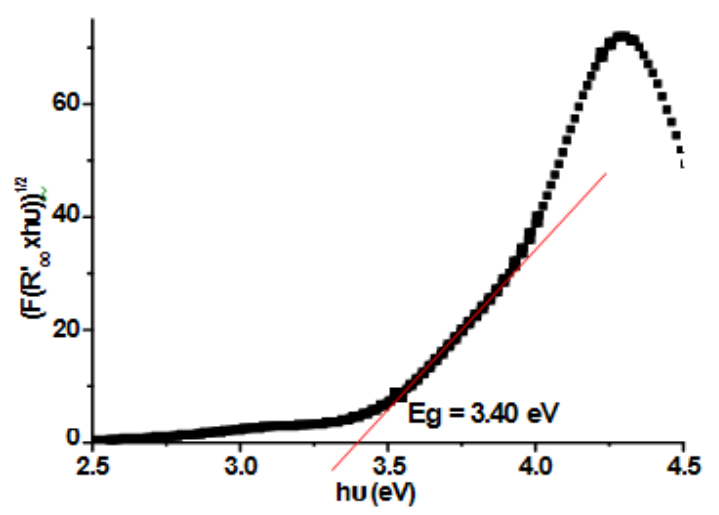

(a)

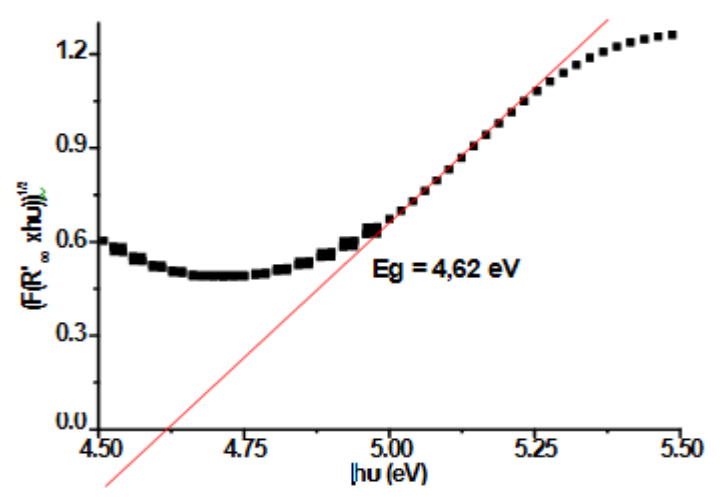

(b)

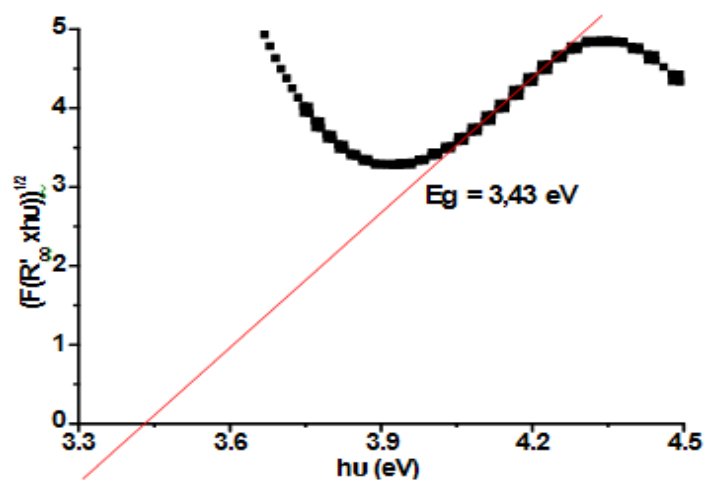

(Table 3). The values of $\mathrm{R}^{2}$ of Langmuir adsorption isotherm pattern are higher than the value of $R^{2}$ of Freundich adsorption isotherm pattern, leading the conclusion that the adsorption of methylene blue by the (Ni-Cu)Ox@ $\mathrm{SiO}_{2}$ follows the Langmuir isotherm pattern. This model assumes that there is only a surface layer (monolayer) and is homogeneous of ( $\mathrm{Ni}-\mathrm{Cu}) \mathrm{Ox}$ on the surface of $\mathrm{SiO}_{2}$ which can block adsorption into deeper layers.

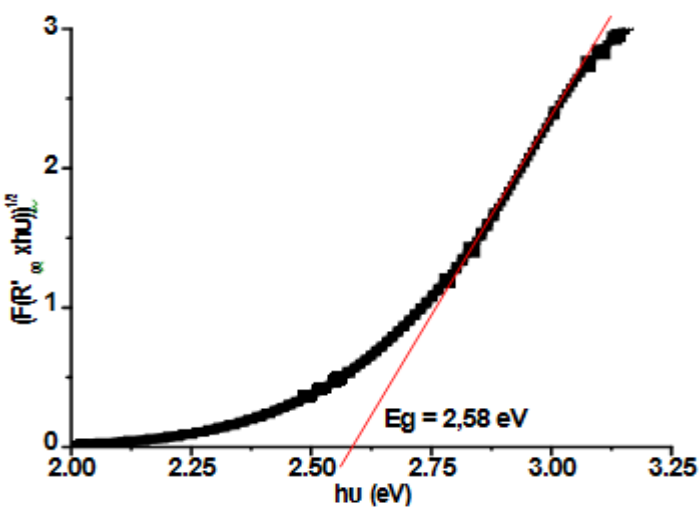

(a)
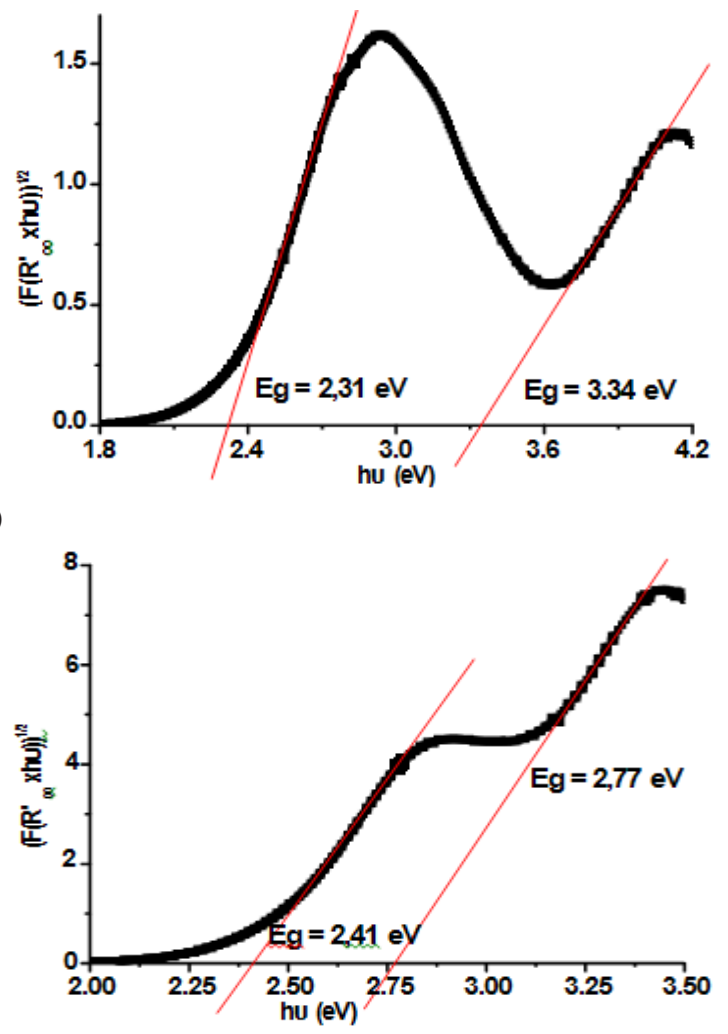

(c)

Fig. 4. The calculation of $(\mathrm{Ni}-\mathrm{Cu}) \mathrm{Ox} @ \mathrm{SiO}_{2}, \mathrm{Ni}: \mathrm{Cu}=$ (a) 0.3:0.0 (b) 0.2:0.1 and (c) 0.15:0.15, band gap energies 


\begin{tabular}{cccc}
$\begin{array}{r}\text { Table 2: } \\
\text { after adsorption by (Ni-Cu)Ox @ } \text { SiO }_{2}\end{array}$ \\
$\begin{array}{cccc}\text { Time } \\
(\mathrm{min})\end{array}$ & $\begin{array}{r}\text { The concentration of methylene blue }(\mathrm{ppm}) \text { after } \\
\text { adsorption by }\end{array}$ \\
\hline & $0.3 \mathrm{Ni}-\mathrm{Cu}) \mathrm{Ox} @ \mathrm{SiO}_{2}$, for Ni:Cu $=$ \\
\hline & 8.66727 & 8.66727 & 8.66727 \\
5 & 5.49894 & 5.49894 & 5.49894 \\
10 & 2.47603 & 2.37215 & 2.36176 \\
15 & 1.88911 & 2.28905 & 2.13842 \\
20 & 1.75926 & 1.87872 & 1.16714 \\
25 & 1.74368 & 1.54630 & 1.11001 \\
35 & 1.55669 & 1.52553 & 0.87628 \\
65 & 1.43204 & 1.41126 & 0.55945 \\
95 & 1.42684 & 1.37490 & 0.55438 \\
125 & 1.01652 & 0.96977 & 0.54910 \\
\hline
\end{tabular}

Table 3: Langmuir and Freundlich isotherm's line equations

\begin{tabular}{ccc}
\hline $\begin{array}{c}(\mathrm{Ni}-\mathrm{Cu}) \mathrm{Ox} @ \mathrm{SiO}_{2}, \\
\mathrm{Ni}: \mathrm{Cu}=\end{array}$ & $\begin{array}{l}\text { Langmuir } \\
\text { isotherm }\end{array}$ & $\begin{array}{l}\text { Freundlich } \\
\text { isotherm }\end{array}$ \\
\hline $0.3: 0.0$ & $\mathrm{y}=0.0743 \mathrm{x}-0.0736$ & $\mathrm{y}=-0.5398 \mathrm{x}+1.6498$ \\
& $\mathrm{R}=0.9757$ & $\mathrm{R}^{2}=0.898$ \\
$0.2: 0.1$ & $\mathrm{R}^{2}=0.9695$ & $\mathrm{y}=-0.516 \mathrm{x}+1.6422$ \\
& $\mathrm{y}=0.0665 \mathrm{x}-0.0428$ & $\mathrm{y}=-0.369 \mathrm{x}+1.5679$ \\
$0.15: 0.15$ & $\mathrm{R}^{2}=0.955$ & $\mathrm{R}^{2}=0.8247$ \\
\hline
\end{tabular}

The catalyst adsorption capacity can be calculated by using the line equation of the Langmuir isotherm pattern. The adsorption capacity of ( $\mathrm{Ni}-\mathrm{Cu})$ $\mathrm{Ox} @ \mathrm{SiO}_{2}$ catalyst is listed in Table 4. The decreasing of $\mathrm{NiOx}$ and the increasing of $\mathrm{CuOx}$ is related linearly with the increasing of the adsorsobtion capacity of $(\mathrm{Ni}-\mathrm{Cu}) \mathrm{Ox} @ \mathrm{SiO}_{2}$ catalyst to methylene blue.

\begin{tabular}{|c|c|}
\hline $\begin{array}{c}(\mathrm{Ni}-\mathrm{Cu}) \mathrm{Ox} @ \mathrm{SiO}_{2}, \\
\mathrm{Ni}: \mathrm{Cu}=\end{array}$ & $\begin{array}{l}\text { Adsorption capacity } \\
\qquad(\mathrm{mol} / \mathrm{g})\end{array}$ \\
\hline 0.3:0.0 & 13.5870 \\
\hline $0.2: 0.1$ & 13.9082 \\
\hline $0.15: 0.15$ & 23.3645 \\
\hline
\end{tabular}

The concentration of methylene blue isolated in the dark for $24 \mathrm{~h}$ is higher than for $2 \mathrm{~h}$ might be due to desorption process. The methylene blue in the solution was then exposed to sunlight for period of times. The concentration of methylene blue after exposed by sunlight at period of times is presented in (Fig. 5). The concentation of methylene blue is gradually decreased at the first 20 minutes. The concentration is then steady figuring that the photodegration is finished. The percentages of methylene blue photodegradated under sunlight using (Ni-Cu)Ox@SiO, where Ni:Cu=0.3:0, 0.2:0.1 and 1.5:1.5 are $55.65 \%, 49.87 \%$, and $52.11 \%$, respectively.

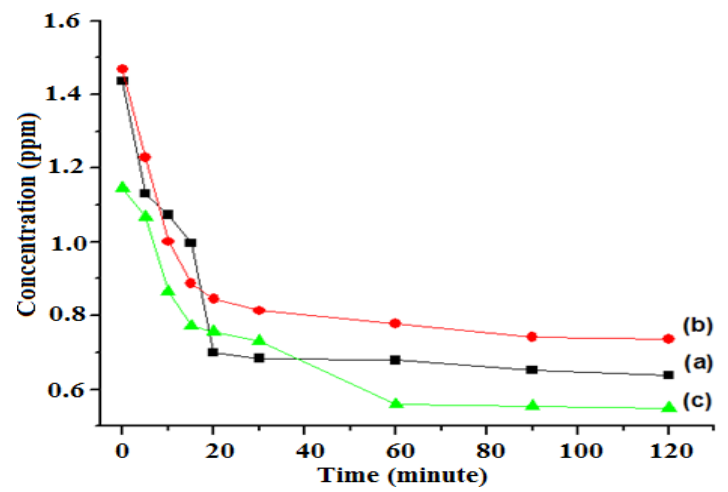

Fig. 5. The methylene blue photodegradation under sunlight using (Ni-Cu)Ox@ $\mathrm{SiO}_{2}$, where $\mathrm{Ni}: \mathrm{Cu}=(\mathrm{a})$ 0.3:0, (b) 0.2:0.1 and (c) 1.5:1.5

The reaction order kinetics for photodegradation of methylene blue are presented in (Table 5). The highest $R^{2}$ values indicate the second reaction order. These is meant that the photodegradation reaction rate of methylene blue using the (Ni-Cu)Ox@ $\mathrm{SiO}_{2}$ catalyst under sunlight follows the second-order reaction.

Table 5. Methylene blue photodegradation order kinetics

\begin{tabular}{cccc}
\hline $\begin{array}{c}\text { (Ni-Cu)Ox@ } \mathrm{SiO}_{2}, \\
\mathrm{Ni}: \mathrm{Cu}=\end{array}$ & Order & $\mathrm{k}$ & $\mathrm{R}^{2}$ \\
\hline $0.3: 0.0$ & 0 & 0.0036 & 0.5293 \\
& 1 & 0.0043 & 0.5565 \\
& 2 & 0.0053 & 0.5866 \\
$0.2: 0.1$ & 0 & 0.0028 & 0.5148 \\
& 1 & 0.0031 & 0.5812 \\
$0.15: 0.15$ & 2 & 0.0036 & 0.6476 \\
& 0 & 0.0036 & 0.6903 \\
& 1 & 0.005 & 0.7631 \\
& 2 & 0.0071 & 0.8169 \\
\hline
\end{tabular}

The photocatalytic reaction takes place in a heterogeneous system and the reaction rate is influenced by the adsorbance of the reactants on the surface of the catalyst. The kinetic constant $\mathrm{k}_{\mathrm{obs}}$ is the reaction rate constant that does not take into account the role of adsorption, so that when the adsorption process becomes a part that affects the photodegradation reaction, it is necessary to determine the actual reaction rate constant $(\mathrm{k})$ which has corrected the $\mathrm{k}_{\mathrm{obs}}$ with the adsorption constant (K) where $\mathrm{k}_{\mathrm{obs}}=\mathrm{kKL}$. The kinetics parameters of the $\mathrm{k}_{\mathrm{obs}}$ are determined by fitting the curve $1 / \mathrm{C}_{\mathrm{t}}$ to the time due to the photodegradation reaction of methylene blue with ( $\mathrm{Ni}-\mathrm{Cu}) \mathrm{Ox} @ \mathrm{SiO}_{2}$ following a second-order reaction. Then the reaction rate constant $(\mathrm{k})$ is determined based on the $\mathrm{k}_{\mathrm{obs}}$ listed in (Table 6). The (Ni-Cu)Ox@ $\mathrm{SiO}_{2}, \mathrm{Ni}: \mathrm{Cu}=0.15: 0.15$ shows the highest photodegradation reaction rate 
constant of methylene blue under sunlight, which is $0.10677 \cdot 10^{4} \mathrm{~min}^{-1}$. This concludes that the $(\mathrm{Ni}-\mathrm{Cu})$ $\mathrm{Ox} @ \mathrm{SiO}_{2}, \mathrm{Ni}: \mathrm{Cu}=0.15: 0.15$ is most effectively used as a photocatalyst under sunlight.

Table 6: Methylene blue photodegradation kinetics using $\mathrm{Ni}-\mathrm{Cu}$ oxide@ $\mathrm{SiO}_{2}$ catalyst

\begin{tabular}{cccc}
\hline $\begin{array}{c}(\mathrm{Ni}-\mathrm{Cu}) \mathrm{Ox} @ \mathrm{SiO}_{2}, \\
\mathrm{Ni}: \mathrm{Cu}=\end{array}$ & $K_{L}$ & $\mathrm{k}_{\text {obs }}\left(\mathrm{min}^{-1}\right)$ & $\mathrm{k}\left(\mathrm{min}^{-1}\right)$ \\
\hline $0.3: 0.0$ & $0.0743 \cdot 10^{6}$ & 0.0053 & $0.07133 \cdot 10^{4}$ \\
$0.2: 0.1$ & $0.0734 \cdot 10^{6}$ & 0.0036 & $0.04905 \cdot 10^{4}$ \\
$0.15: 0.15$ & $0.0665 \cdot 10^{6}$ & 0.0071 & $0.10677 \cdot 10^{4}$ \\
\hline
\end{tabular}

The photodegradation reaction rates of methylene blue are listed in (Table 7). The difference in $\mathrm{Ni}$ and $\mathrm{Cu}$ concentrations supported onto silica does not have a significant effect on the photodegradation reaction rate equation. This proves that the $(\mathrm{Ni}-\mathrm{Cu})$ $\mathrm{Ox} @ \mathrm{SiO}_{2}$ catalyst is effective for photodegradation of methylene blue under sunlight.

Table 7: Methylene blue photodegradation rate

\begin{tabular}{cc}
\hline (Ni-Cu)Ox@ $\mathrm{SiO}_{2}, \mathrm{Ni}: \mathrm{Cu}=$ & Reaction rate $(\mathrm{ppm} /$ minute $)$ \\
\hline $0.3: 0.0$ & $0.07133 \cdot 10^{4} \times \mathrm{C}^{2}$ \\
$0.2: 0.1$ & $0.04905 \cdot 10^{4} \times \mathrm{C}^{2}$ \\
$0.15: 0.15$ & $0.10677 \cdot 10^{4} \times \mathrm{C}^{2}$ \\
\hline
\end{tabular}

\section{CONCLUSION}

The prepared $(\mathrm{Ni}-\mathrm{Cu}) \mathrm{Ox} @ \mathrm{SiO}_{2}$ is representative for photodegradation of methylene blue. The nickel and copper oxides decrese the bandgap of silica making the catalyst suitable for photodegradation under visible and ultra violet lights. The catalyst adsorption follows the Langmuir isotherm pattern with adsorption capacity of (Ni-Cu)Ox@ $\mathrm{SiO}_{2}$ increases along with the increasing of copper oxide. The photocatalytic activity of the catalyst in the degradation of methylene blue under the sunlight follows a second order reaction rate.

\section{ACKNOWLEDGMENT}

This research was supported and fully funded by the Yogyakarta State University of Indonesia.

\section{Conflict of interest}

The authors declare that there is no conflict of interests regarding the publication of this article.

\section{REFERENCE}

1. Paraschiv, D.; Tudor, C.; Petrariu, R., Sustainability, 2015, 7, 1280-1291.

2. Ananthashankar, R.A.G., J. Chem. Eng. Process Technol., 2013, 05, 3. Kant, R., Nat. Sci., 2012, 04, 22-26.

4. Aljeboree, A. M.; Alshirifi, A. N.; Alkaim, A. F., Arab. J. Chem., 2017, 10, S3381-S3393.

5. Konsowa, A.H.;Ossman, M.E.;Chen, Y.; Crittenden, J. C., J. Hazard. Mater., 2010, 176, 181-185.

6. Zhou, X.T.; Ji, H.B.; Huang, X. J., Molecules., 2012, 17, 1149-1158.

7. Wan, J.; Sun, L.; Liu, E.; Fan, J.; Hu, X.; Pu, C.; Li, J.; Du, X., Mater. Lett., 2016, 169, 189-192.

8. Harraz, F.A.; Mohamed, R.M.;Rashad, M.M.;Wang, Y. C.; Sigmund, W., Ceram. Int., 2014, 40, 375-384.

9. Borges, M. E.; Sierra, M.; Cuevas, E.; García, R.D.; Esparza, P., Sol. Energy., 2016, 135, 527-535.

10. Tian, C. Chem. Commun., 2012, 48, 2858.

11. Soltani, N.; Saion, E.; Hussein, M.Z.; Erfani, M.; Abedini, A.;Bahmanrokh, G.; Navasery, M.; Vaziri, P., Int. J. Mol. Sci., 2012, 13, 12242-12258.

12. Khaki, M. R. D.; Shafeeyan, M. S.; Raman, A. A. A., Journal of Environmental Management., 2017, 198, 78-94.

13. Tada, H.; Jin, Q.; Nishijima, H.; Yamamoto, H.; Fujishima, M.; Okuoka, S.; Hattori, T.; Sumida,
Y.; Kobayashi, H., Angew. Chemie Int. Ed., 2011, 50, 3501- 3505.

14. Maucec, D.; Maucec, D.; Šuligoj, A.; Ristic, A.; Dražic, G.; Pintar, A.; Tušar, N.T., Catal. Today., 2018, 310, 32-41.

15. Chen, Y.; Wang, K.; Lou, L., J. Photochem. Photobiol. A Chem., 2004, 163, 281-287.

16. Koshy, J.; Samuel, M.S.; Chandran, A.; George, K.C.; Predeep, P.; Thakur, M.; Varma, M. K. R., AIP Conference Proceedings., 2011, -, 576-578.

17. Fujita, S.;Kawamori, H.;Honda, D.;Yoshida, H.;Arai, M., Appl. Catal. B Environ., 2016, 181, 818-824.

18. Monshi, A.; Foroughi, M. R.; Monshi, M. R., World J. Nano Sci. Eng., 2012, 02, 417-430.

19. Holzwarth, U.; Gibson, N., Nat. Nanotechnol., 2011, 6, 534-534.

20. Myrick, M.L.; Simcock, M.; Baranowski, M.; Brooke, H.; Morgan, S.; McCutcheon, J., Appl. Spectrosc. Rev., 2011, 46, 140-165.

21. Hufner, S.; Steiner, P.; Sander, I.; Reinert, F.; Schmitt, H., Zeitschrift fur Phys. B Condens. Matter., 1992, 86, 207-215.

22. Abdel Rafea, M.; Roushdy, N., J. Phys. D. Appl. Phys., 2009, 42, 015413.

23. LeVan, M. D.; Vermeulen, T., J. Phys. Chem., 1981, 85, 3247-3250. 